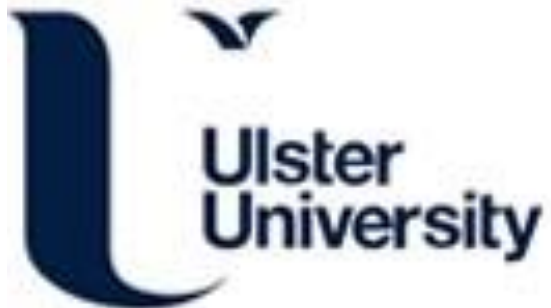

\section{Capital Flows and Office Markets in Major Global Cities}

Fadeyi, O., Mc Greal, S., McCord, M., \& Berry, J. (2020). Capital Flows and Office Markets in Major Global Cities. Journal of Property Investment and Finance, 0, 1-25. https://doi.org/10.1108/JPIF-02-2020-0023

Link to publication record in Ulster University Research Portal

\section{Published in:}

Journal of Property Investment and Finance

\section{Publication Status:}

Published online: $21 / 07 / 2020$

DOI:

10.1108/JPIF-02-2020-0023

\section{Document Version}

Author Accepted version

\section{General rights}

Copyright for the publications made accessible via Ulster University's Research Portal is retained by the author(s) and / or other copyright owners and it is a condition of accessing these publications that users recognise and abide by the legal requirements associated with these rights.

\section{Take down policy}

The Research Portal is Ulster University's institutional repository that provides access to Ulster's research outputs. Every effort has been made to ensure that content in the Research Portal does not infringe any person's rights, or applicable UK laws. If you discover content in the Research Portal that you believe breaches copyright or violates any law, please contact pure-support@ulster.ac.uk. 


\section{Pemerald}

'This author accepted manuscript is deposited under a Creative Commons Attribution Non-commercial 4.0 International (CC BY-NC) licence. This means that anyone may distribute, adapt, and build upon the work for non-commercial purposes, subject to full attribution. If you wish to use this manuscript for commercial purposes, please contact permissions@emerald.com.' 


\section{Journal of Property Investment \& F}

\section{Capital Flows and Office Markets in Major Global Cities}

\begin{tabular}{|r|l|}
\hline Journal: & Journal of Property Investment \& Finance \\
\hline Manuscript ID & JPIF-02-2020-0023.R2 \\
\hline Manuscript Type: & Academic Paper \\
\hline Keywords: & $\begin{array}{l}\text { Office market, Global cities, International investments, Granger } \\
\text { causality, Auto-regressive Distributed Lag Approach (ARDL), } \\
\text { Cointegration }\end{array}$ \\
\hline \multicolumn{2}{|l}{} \\
\hline
\end{tabular}

SCHOLARONE ${ }^{m}$

Manuscripts 


\title{
Capital Flows and Office Markets in Major Global Cities.
}

\begin{abstract}
Purpose - Office markets and particularly international financial centres over the past decade have experienced rapid financialisation, developments and indeed changes in the post Global Financial Crisis landscape. Importantly, the volume and types of international capital flows have witnessed more foreign actors and vehicles entering the investment landscape with the concentration of investment intensifying within key financial centres. This paper examines the interaction of international real estate capital flows in the London, New York and Tokyo office markets between 2007 and 2017.
\end{abstract}

Design/methodology/approach - Using Real Capital Analytics (RCA) data comprising over 5,700 office property transactions equating to $\$ 563 \mathrm{~B}$ between 2007 and 2017, the direct global capital flows into the London, New York and Tokyo office markets are assessed using AutoRegressive Distributed Lag (ARDL) models. Further, Granger causality tests are examined to analyse the short-run interaction of international real estate capital flows into these three major office markets.

Findings - By assessing the relativity of internal to external investments in these three CBD office markets, differences in market dynamics are highlighted. The London market is shown to be highly dependent on international flows with the US market the foremost source of crossborder investment on the global stage. The co-integration and causality analysis indicate that cross-border real estate investment flows in these markets (and financial centres) show both long- and short-run relationships and suggest that the London market remains more distinct and the most reliant on international capital flows with a wider geographical spread of investment activities and investor types. In the case of New York and Tokyo, these markets appear to be driven by more domestic investment activity and capital. This is seemingly due to subtle factors pertaining to investor home bias, risk aversion and diversification strategies between the markets in the aftermath of the Global Financial Crisis.

Originality/value - Given the importance of the CBD offices in London, New York and Tokyo as an asset class for institutional investors, this paper provides some insights as to their level of connection and the interaction of the international capital flows into these three major cities.

Keywords - Office market, Global cities, International investments, Granger causality, Autoregressive Distributed Lag Approach (ARDL), Cointegration. 


\section{Introduction}

In an expanding era of economic globalisation, the scope and nature of international capital flows are maturing with its active presence visible across all markets. Indeed, since the 1990s, international financialisation, foreign investment and capital movements have played an important role in many market crises due to risk in relation to their super-liquidity and speculation (Cai, 2018). As a pillar industry of the global economy, and with office markets an integral component of capital flows, the nexus between global cities and global financial markets has intensified (Lizieri, 2012).

Indeed, office markets in major global financial centres/cities, specifically in London, New York and Tokyo, are not only significant to their respective national economy, but also crucial in the global economy, attracting international investment with increasing interest in real estate as an asset class especially by foreign investors (Newell and McGreal, 2017; Cai, 2018; Su, 2018). This is indicative of reported growth in the allocation of investors' funds to real estate with the rise in global real estate capital flows largely due to the asset's distinctive and unique characteristics. In particular, the real estate asset performance relative to other major investment assets such as bonds and stocks, as well as its diversification potential within a multi-asset portfolio, reflects the role of real estate as a core investment medium (Lizieri, 2009; Baum, 2015). Moreover, as outlined by Lizieri (2009), the overall growth in global real estate capital flows is continuing to be enhanced by innovation in real estate investment vehicles and globalisation, amongst other competing factors (Lizieri, 2009).

Despite the sharp contraction in real estate investment during the Global Financial Crisis (GFC), momentum has gained traction since 2009 with market recovery driven by renewed interest in cross-border investment activity by a wider pool of investors and changing geographies (Newell et al., 2010). Furthermore, the emergence of more noteworthy market participants (Sovereign Wealth Funds, Endowment Funds, Investment Banks), the development of new real estate investment vehicles and the availability of debt financing are factors stimulating interest in, and paving the way for, cross-border real estate investment.

Whilst the underlying rationale behind international diversification is the interconnection between asset performance and economic fundamentals (Stevenson et al., 2014), real estate investment is mostly concentrated in prime locations, particularly the office markets, in the 
Consequently, given this context, this paper provides an investigation into the interrelationships and connectivity between office market investment in London, New York and Tokyo over the period 2007 to 2017. This is realised through assessing the trends, the relativity of internal to external investment in each of these CBD office markets with specific analysis by country of origin, investor type and the level of inter-linkages between these CBD office markets.

\section{Literature Review: capital market flows}

Real estate, especially office markets are a significant component of global cities. According to Lizieri and Pain (2014) real estate provides the physical structure for production process and is the physical manifestation of city networks which coordinate the global financial flows. Indeed, Lizieri and Pain (2014) suggest that this process is linked to the (re)development of prime office markets and the growing concentration of functional specialized activity of advance producer services (APS) firms. The literature highlights how offices in global financial centres interlock occupation, ownership and finance, through the growing globalization of real estate ownership and innovation in real estate investment vehicles, thereby integrating finance and real estate in global and globalizing cities (Lizieri, 2009; Lizieri and Pain, 2014).

\footnotetext{
${ }^{1}$ Such as the AT Kearney Global Cities Index, MORI Global Power City Index, PwC's Cities of Opportunity, Z/Yen Global Financial Centres Index and IESE Cities in Motion Index.
} 
Real estate markets in global cities are the major destinations for capital flows thereby strengthening their connection with the global financial markets. For example, PGIM Real Estate (2016) reported a significant increase in the share of total real estate investment going to top eight global cities (including London, New York and Tokyo) taking an estimated onethird the total transaction volume at the end of 2015; significantly more than the pre-financial crisis level. In a similar vein, Hoyler et al. (2014) in an examination of the relationship between international real estate investment flows and city connectivity found that global cities with high financial and APS connectivity have high international real estate capital inflows implying the concentration of international office investments in global cities. Indeed, Hoyler et al. (2014) suggest that international real estate investment inflow is a proxy for global financial networks, and numerous studies (Lizieri and Pain, 2014; Stevenson et al., 2014; McAllister and Nanda, 2015) have explored the consequences of such capital flow concentration within global cities. Pertinently, Lizieri and Pain (2014) argue that such concentration whilst increasing returns performance also enhances exposure to international financial market risk. In advancing these arguments, McAllister and Nanda (2015) contended that the concentration of foreign investments leads to yield compression in the office sector due to the increase in the intensity of competition for limited suitable products. Concomitantly, Hoyler et al. (2014) illustrated that global cities are often considered 'safe havens' for investors, as demonstrated by the 'flight to prime' during and after the GFC principally due to the transparency, intrinsic value and liquidity within these cities.

Research conducted by Dhar and Goeztmann (2005) evaluated factors that influence institutional investors and their allocation to real estate. In a survey of major institutional investors, such as corporate and public pension funds, they highlighted liquidity to be the primary risk factor within the real estate allocation decision process. Based on modern portfolio theory, their study illustrated institutional investors reliance on availability of data for longterm estimates of risk adjusted returns or performance. Indeed, the availability of reliable real estate data as well as investors' confidence in such data are enhanced by market transparency and explains investors' predisposition to real estate investment in a transparent market such as global cities. 
Ling et al. (2009) scrutinised the dynamics of asset prices and transaction activity in private commercial real estate markets, particularly in terms of illiquidity. Investigating the empirical relationship among capital flows, turnover and asset prices in the UK private commercial real estate market and utilising a panel vector autoregressive (VAR) regression specification, Ling et al. (2009) revealed that capital appreciation is positively and significantly correlated with contemporaneous capital flows, percentage capital flows, and asset turnover. Interestingly, they found a positive significant relationship with changes in economic output which was inferred to indicate a joint dependency of capital appreciation and economic activity. Moreover, they considered that capital appreciation is positively correlated with lagged capital flows and turnover, further indicating positive relationships between capital appreciation and transaction activity which they attributed to return chasing behaviour on the part of investors in private real estate markets.

In a similar paper, Fisher et al. (2009) investigated the short- and long-run dynamics amongst institutional capital flows and returns in private commercial real estate markets. More specifically, they examined whether net capital flows impact asset prices and returns in a crosssectional analysis of US property sectors and geographic markets. Simultaneously, they examined whether the returns earned by institutional investors impact their subsequent net acquisitions and dispositions. At the aggregate US level, the authors showed that institutional capital flows have a statistically and economically significant influence on subsequent returns. However, when disaggregating by property type at the national level, they found mixed results and detected no evidence of return-chasing behaviour. In a more market cycle orientated approach, Fisher et al.(2007) evaluated the role of capital flows in terms of short- and longrun dynamics of institutional capital flows and returns in private real estate markets using a

\footnotetext{
2 The JLL (2016) Global Real Estate Transparency Index evaluates real estate market transparency in terms of availability of data, fairness of transaction processes, and quality of governance, property rights, and the regulatory / legal environment and covers 109 real estate markets.
} 
VAR model controlling for financial and economic variables. They found some evidence that lagged NCREIF returns and lagged NCREIF flows influence current returns though when accounting for the more granular cross-sectional variation across different metropolitan areas and property types. They found no evidence that returns are predictive of future NPI capital flows.

In keeping with the analysis of the commercial real estate sector, Newell et al.(2010) assessed the robustness of capital flows relative to developed and developing European commercial property markets during the GFC. Utilising RCA transactional evidence of over 49,000 commercial properties valued at over $\$ 1.5$ trillion, they examined capital flows at both a global and regional context and the interplay between the markets. Their results illustrated manifest differences in capital flows at all levels and tiers across a range of property investment characteristics. In terms of capital flow-return relationships in the mutual fund sector, Ling and Naranjo (2003) investigated publicly traded real estate investments; namely, US REITs to establish whether capital flows impact upon REIT returns, and simultaneously, the effects of REIT returns on subsequent REIT capital flows. Using a dynamic VAR approach estimating the short-rand long-run relationships, impulse response functions and forecast variance decompositions, the authors revealed that REIT equity flows are positively related to a twoquarter lag but limited evidence that lagged REIT flows influence future returns. In a similar study Ling and Naranjo (2006) also inspected the short and long-run dynamics between capital flows to REIT mutual funds and aggregate REIT returns. In line with their original study they found no evidence that mutual fund flows are associated with subsequent REIT returns, but did find that REIT mutual fund flows exhibit return-chasing behaviour with flows positively and significantly related to lagged returns.

A number of studies into capital flows that focused on the Chinese market include the interactivity of the stock market and real estate market. Testing the impact of short-term international capital flows based on the "Co-Selling Effect" theory, Zhang (2018) suggest that an effect exists when market conditions are poor, however note that this is not observed when market conditions are normal. Cai (2018) in a slightly different approach evaluated the relationship between the flow of international short-term capital and property pricing showing that the inflow of international short-term funds to the real estate market in China has a positive impact on the real estate market, and to a certain extent has promoted real estate price developments. 
There has also been extensive research examining Foreign Direct Investment (FDI) capital flows. The study by Scott-Green and Clegg (1999) examined the linkages between European integration and FDI foreign direct investment. Utilising comparable US and Japanese data on new FDI flows between 1984 and 1989, the authors pooled the data to enable intra-EC differences to be investigated, illustrating that FDI is linked to conventional host characteristics variables whose effects vary considerably between groups of member countries, with Japanese firms more significantly impacted. Similarly, early research by Lipsey et al. (1999) scrutinised the role of FDI in international capital flows and market integration finding that the US was the foremost source of direct investment outflows from the 1970s with Japan and Europe catching up in the 1980s and 1990s. During this period, the US shifted from being the largest global net supplier of direct investment to being an absorber especially between 1985-1989 with Japan primarily dominating portfolio capital channelled via direct investment outflows. Pertinently, Lipsey et al. (1999) illustrated that direct investment, as a flow of capital, is only partially related to the activities of multinational enterprises (MNEs), nonetheless, the authors suggest that direct US investment abroad is more important than in total foreign investment by other countries and far more important than in foreign investment in the United States. In their opinion, the reason for the relative stability of direct investment flows pertains to the importance of retained earnings which they claim rarely shift within established firms in established financial centres and seemingly appear to be the most important in outward US and UK investment.

Razin (2002) investigated the theoretical dimension of FDI investment, principally 'hands-on' management standards, that enable investors to react in real time to a changing economic environment. The analysis showed that foreign direct investors are able to outbid portfolio investors and consequently make investment, both larger, and of higher quality (namely, with large rates of returns), than domestic investors which suggests explains both two-way FDI flows among developed countries. Indeed, the author's panel data shows larger FDI coefficients in the domestic investment and output growth regressions relative to the portfolio equity flow and international loan coefficients, reflective of a more significant role for FDI in the domestic investment process than other types of capital inflows.

Alfaro et al. (2004) examined the various links among FDI, financial markets and economic growth by exploring if countries with better financial systems can exploit FDI more efficiently. Applying cross-country data over a twenty-year period between 1975 and 1995, their findings 
indicate that countries with established financial markets gain significantly from FDI flows with the level of development of local financial markets crucial for these effects to be realised. Significantly, the authors provide evidence that the link between FDI and growth is causal, where FDI promotes growth through financial markets. In a similar study, Aizenman et al. (2013) investigated the relationship between economic growth and lagged international capital flows, disaggregated into FDI, portfolio investment, equity investment, and short-term debt for 100 countries during the period 1990-2010. Specifically investigating pre- and post-GFC relationships, the findings revealed that the relationship between growth and lagged capital flows depends on the type of flows, economic structure, and global growth patterns. Interestingly, the authors found large and robust relationships between FDI - both inflows and outflows - and economic growth, however they also illustrated that the association between growth and equity flows is smaller and less stable with growth and short-term debt before the crisis, and negative during the crisis.

The study by Globerman and Shapiro (2002) concentrated on examining global FDI flows in relation to 'governance infrastructure', namely the political, institutional and legal environment. Employing indices to examine the effects of governance infrastructure on FDI inflows and outflows over the period 1995 to 1997, they found that governance infrastructure is an important determinant of both FDI inflows and outflows and suggested that investments in governance infrastructure not only attract capital, but also create the conditions under which domestic multinational corporations emerge and invest abroad.

In a comparable study, Moshirian and Pham (2000) analysed the determinants of US investment (FDI) with foreign real estate markets. Their empirical results showed that as US foreign financial liabilities increase, there is an accompanying increase in its FDI in real estate. Interestingly it is inferred that US FDI abroad is a substitute for US financial assets, in that as returns from the US stock market decline, there are more incentives for US investors to invest in foreign real estate. The results showed that US financial wealth, US FDI in manufacturing and banking, US bilateral trade, foreign current account balance and US foreign financial liabilities contribute positively to the expansion of US FDI in real estate.

Milesi-Ferretti and Tille (2011) explored international capital flows during the GFC in the wake of the unprecedented collapse in international capital flows due to financial globalisation. Examining the stylised facts, they attribute the retrenchment in international capital flows to 
Overall, there is a rich literature base pertaining to the determinant of international capital flows as well as the nexus between capital flows, FDI and real estate. In terms of real estate capital flows, majority of these studies have examined the capital flows relative to asset pricing, behaviour and transaction activity relative to investment risk and increases in property values. However, there is limited analytical insights investigating international real estate capital flows at the city level. Whilst these three major office markets have been incorporated into some existing studies, there remains limited empirical evidence that explicitly investigates the interaction of the international capital flows in and between these three major cities.

\section{Data and Methodology}

The evaluation of the cross-border investment activities in London, New York and Tokyo is based upon CBD office property transactions assessed over the period 2007 to 2017 using data sourced from Real Capital Analytics (RCA) ${ }^{3}$. RCA tracks the sale of income-producing property (including development sites) and portfolios transacted at a minimum of $\$ 10$ million in 172 countries in the Americas, Europe, Middle East and Africa and Asia-Pacific. The

\footnotetext{
${ }^{3}$ Real Capital Analytics (RCA) is an independent property research organisation, which provides the largest, most comprehensive and extensively used international commercial property capital flows database by major institutional investors and the research community.
} 
database provides deal information behind the $\$ 18$ trillion property transactions capturing aspects such as the origin and destination of the investment flows, investors profile and property types for measuring global real estate investments trends. For this research, we have utilised the annual total deal and the quarterly cross-border deal flow information for the three cities over the period 2007-2017.

The analytics underpinning this paper initially uses descriptive statistics to investigate the scale of cross-border investment flows at a global level by volume of activities and investor type. Secondly, time series analysis is used to examine the cointegration and causality of office market capital flows into the three selected cities (London, New York and Tokyo), focusing on the level of inter-linkages between these markets ${ }^{4}$, based on quarterly volume derived from RCA data.

\section{ADF Unit Root Tests}

Prior to carrying out the analysis, it is statically crucial to detect, if any, the presence of unit roots of the time series. Failure to account for the stationarity of the data could lead to spurious regressions, undermining the reliability of inference (Granger and Newbold, 1974; Banerjee et al., 1993). Accordingly, we utilise the Augmented Dickey-Fuller (ADF) unit test to check for the stationarity of the time series, whose general equation is shown below:

$$
\Delta Y_{t}=\alpha+\beta T+\emptyset Y_{t-1}+\sum_{i=1}^{k} \partial \Delta Y_{t-i}+\varepsilon_{t}
$$

where $Y_{t}$ is the level of the time series in question; $\alpha$ is an intercept term and $T$ is a temporal trend; $k$ indicates the number of time periods for achieving white noise, which is determined and guided by Schwarz information criterion; and $\varepsilon_{t}$ is an error term with mean equal to zero and constant variances.

\section{Cointegration Tests}

To establish whether long-run equilibrium cointegration relationships between the time series are present, the Johansen Cointegration test is employed (Johansen, 1991; 1995). This approach

\footnotetext{
4 We were only able to obtain data for the total capital inflows into office markets for the three cities under investigation. Therefore, the study is limited to the investigation of the interlinkages between these cities.
} 
establishes that the components of a vector $V_{t}$ are said to be cointegrated of order $\mathrm{i}, \mathrm{j}$, which can be mathematically represented by $V_{t} \sim \mathrm{CI}(\mathrm{i}, \mathrm{j})$ if $V_{t}$ is I(i) and we can find a non-zero vector $\alpha$ such that $\alpha^{\prime} V_{t} \sim \mathrm{I}(\mathrm{i}-\mathrm{j})$ where $\mathrm{i} \geq \mathrm{j}>0$. $\alpha$ is known as cointegrating vector. Cointegration exists if there is a long-term equilibrium relationship between these time series. To statistically confirm whether there exists, cointegration relation between two $I(1)$ time series, say, $X_{t}$ and $Y_{t}$ , Engle and Granger (1987) suggests running a regression of $Y_{t}$ on $X_{t}$. Stationarity tests are then employed to check the presence or absence of unit root(s) in the regression residual, $u_{t}$. To this end, the following equation can be constructed:

$$
Y_{t}=\alpha+\beta X_{t}+u_{t}
$$

Equation 2 displays the cointegrating regression, where $X_{t}$ and $Y_{t}$ are cointegrated if and only if $u_{t}$ is a stationary process, which can in turn be confirmed by running the ADF test on $u_{t}$. Nonetheless, Dickey et al. (1991) highlight that the approach suggested by Engle and Granger (1987) could in fact be sensitive to the choice of the regressand(s) by the modeller, potentially resulting in inconsistent estimates. Against this backdrop, Johansen (1991 and 1995) proposed an alternative approach to conducting the cointegration test. Mathematically it is given by:

$$
\Delta Y_{t}=\eta Y_{t-1}+\sum_{i=1}^{k} \mathrm{r}_{i} \Delta Y_{t-i}+B X_{t}+\varepsilon_{t}
$$

where $\eta=\sum_{i=1}^{k} A_{i}-I$ and $\mathrm{r}_{i}=-\sum_{j=1+1}^{k} A_{i} . Y_{t}$ represents a k-vector of $\mathrm{I}(1)$ that is non-stationary. $X_{t}$ is a $d$-vector of deterministic variables and $\varepsilon_{t}$ is a vector of white noises with zero mean and finite variance. The rank of the coefficient matrix is given by $\eta$, which specifies the number of cointegrating vectors in the equation. According to Johansen (1991), the cointegration test should be performed by estimating $\eta$ in an unrestricted form, and consequently determine whether or not the restrictions implied by the reduced rank of $\eta$ can be refuted. The Trace test statistic can thereafter be obtained by conducting the likelihood ratio (LR) test for the hypothesis that there are at most $r$ cointegrating vectors. According to Engle and Granger (1987) variables should have the same order(s), and are integrated of order one in particular.

Although, the Johansen cointegration test (Johansen, 1991) is widely used, the Johansen test method is only applicable if the variables of interest are all integrated to first order, that is $I(1)$. 
Therefore, the method cannot be directly employed if the variables are of mixed order of integration, in this case, the Autoregressive Distributed Lag (ARDL) method is applicable. This paper adopts the ARDL model proposed by Pesaran et al. (2001) to evaluate the inter-linkages between real estate investment flows in these cities. The justification for selecting the ARDL model as opposed to standard VECM model is a consequence of two aspects. Firstly, as alluded to above, the integration of the data order is not consistent when differenced - they are not integrated at the same order, which precludes them from traditional co-integration methodologies. Secondly, as illustrated in the work of Plakandras et al. (2014), the ARDL approach tends to outperform benchmark AR models. Equally, Rapach and Struss (2007) tested an ARDL framework when forecasting and revealed the importance of combining different lag structures for increasing forecast accuracy.

\section{Pairwise Granger-Causality tests}

Furthermore, the analysis also employs the pairwise Granger-causality to determine the direction of the causal relationship among the variables. This approach involves the identification of Granger causality through bivariate (pairwise) regressions. The approach was originally introduced by Granger (1969) in the following form:

$$
\begin{aligned}
& y_{t}=a_{0}+a_{1} y_{t-1}+\ldots . . a_{l} y_{t-l}+B_{1} x_{t-1}+\ldots .+B_{l} x_{t-l}+e_{t} \\
& x_{t}=a_{0}+a_{1} x_{t-1}+\ldots . . a_{l} x_{t-l}+B_{1} y_{t-1}+\ldots .+B_{l} y_{t-l}+u_{t}
\end{aligned}
$$

\section{Office market investment capital flows (London, New York and Tokyo)}

\section{London CBD office market investment capital flows}

The London $\mathrm{CBD}^{5}$ office market capital flow data comprised 2,238 office properties transacted at over $\$ 224 \mathrm{~B}$ over the period 2007-2017, with an average annual investment flow of $\$ 20 \mathrm{~B}^{6}$. Following the peak in 2007 (Figure 1), the value of transactions in the London CBD office market decreased significantly by $63 \%$ from $\$ 33.5 \mathrm{~B}$ in 2007 to $\$ 12.5 \mathrm{~B}$ in 2008 and $\$ 12.1 \mathrm{~B}$ in

\footnotetext{
${ }^{5}$ Central London

${ }^{6}$ All transactions are reported in US dollars ${ }^{6}$ to facilitate comparisons between different countries.
} 
2009, a reduction which is largely due to the impact of the GFC and the decline of investment activity across all economic sectors including the property market. Similarly, in the same period, the number of transactions decreased by $45 \%$ to 156 in 2009 in line with the general decrease in the total transaction volume and generally moving in tandem with the level of investment flows. Following the decline in 2009, the investment flows witnessed a steady upward trend over the period 2009 -2014 characterised by a total increase of over \$17B (142\%) during this period. The number of transactions increased by $64 \%$ to 256 in 2014, indicating an increase in investment activities as the transaction volumes increase, with the exception of 2011 and 2014. In 2011 and 2014 the number of deals declined by 5\% and 4\% respectively despite the recorded $2 \%$ and $9 \%$ increase in investment volumes, thereby implying transactions involving individual investment with greater value.

The subsequent period between 2014 and 2016 indicates a downturn in the value of transactions with a 48\% (\$14B) decrease in CBD office market investment activity. The total investment flows display a marginal fall by $\$ 2.6 \mathrm{~B}$ between 2015 and 2016 . This marginal fall is followed by a significant drop in the level of total investment activity between 2015 and 2016 from \$26.6B to $\$ 15.3 \mathrm{~B}$ (42\%) (arguably due to the impact of Brexit uncertainties). Thus, reflecting an average decrease in total investment flows by \$7B per annum. However, the subsequent year (2017) indicates a slight recovery in the investment activity in London CBD office market despite the lingering political uncertainties. In comparison with total investments in 2016, the investment volume increased by $\$ 1.7 \mathrm{~B}(11 \%)$ to $\$ 17 \mathrm{~B}$ in 2017 , mainly due to the $23 \%$ increase in cross-border investment activities relative to the $52 \%$ decrease in domestic investments. This turnaround could be attributable to changes in international investors' perception of UK political climate, depreciation of Sterling and resilience of London property market as a magnet for investment flows.

\section{$<<<$ Insert Figure 1 $>>>$}

\section{New York CBD office market investment capital flows}

The New York $\mathrm{CBD}^{7}$ office market capital flow data included 1,490 office properties transacted at over \$209B over the period 2007-2017, with an average annual investment flow of $\$ 19 B$. Similar to the trend observed in the London market after the 2007 peak (Figure 2) the

\footnotetext{
7 Including Manhattan, NYC Borough, Stamford, Northern New Jersey
} 
value of transactions in the New York CBD office market also declined, revealing a 94\% decrease from $\$ 32.9 \mathrm{~B}$ in 2007 to $\$ 2.1 \mathrm{~B}$ in 2009 , reflecting the impact of the GFC and the decline of investment activity across all economic sectors including the property market. Similarly, in the same period, the number of transactions decreased by $87 \%$ to 26 in 2009 in line with the general decrease in the total transaction volume and moving in tandem with the level of investment flows. Following the decline in 2009, investment flows increased over the period 2009 -2015 characterised by a total increase in investment flows of over $\$ 27.9 \mathrm{~B}(510 \%)$ in this period. The number of transactions increased by 696\% from 2009 totalling 207 in 2015 , indicating the growth in investment activities as the transaction volumes increased. The subsequent period between 2015 and 2017 indicates a downturn in the value of transactions with a $46 \%(\$ 13.7 \mathrm{~B})$ decrease in CBD office market investment activity in this period amid increasing political uncertainties.

\section{$<<<$ Insert Figure 2 $>>>$}

\section{Tokyo CBD office market investment capital flows}

The Tokyo $\mathrm{CBD}^{8}$ office market capital flow data encompassed 1,999 properties transacted with a total collective value of $\$ 130 \mathrm{~B}$ over the period 2007-2017, with an average annual investment flow of $\$ 11.8 \mathrm{~B}$. The Tokyo investment volume (Figure 3) increased initially between 2007 and 2008 by $7 \%$ ( $\$ 1 \mathrm{~B})$ to $\$ 15.5 \mathrm{~B}$. However, in 2009 , the transaction volume decreased significantly by $38 \%$ to $\$ 10.1 \mathrm{~B}$, reflecting the impact of the GFC and the general decline in investment activities. In the following two-year period, investment flows stabilized with a steady upward trend to a total value of $\$ 12.4 \mathrm{~B}$ in 2011 , indicating an average annual growth of $11 \%$ as the global economy recovered. Between 2007 and 2011 the number of transactions moved in tandem with the transaction volume with an average deal size of \$81.4M. In 2011, following the tsunami and Fukushima Nuclear disaster, while the investment flows decreased by $23 \%$ to $\$ 9.5 \mathrm{~B}$ in 2012 , the number of transactions increased by $10 \%$ to 174 in the same period. Hence, indicating a decrease in the value of the average deal size to $\$ 54.8 \mathrm{~m}$ as capital values contracted. Following the decline in 2012, investment flows increased significantly over the period 2012 to 2014 with a $71 \%$ increase to reach a new peak of \$16.3B in 2014 paralleling the growth in general FDI flows to Japan. Following the 2014 peak, investment flows declined

\footnotetext{
${ }^{8}$ Including the 5 wards and the rest
} 
by $54 \%$ to $\$ 7.5 \mathrm{~B}$ in 2015 amidst sluggish economic growth in Japan. Between 2015 and 2017 the investment flows stabilized with a relatively lower transaction volume, an average of $\$ 8.5 \mathrm{~B}$ per annum. However, the value of the average deal size increased by $36 \%(\$ 13.9 \mathrm{M})$ between 2015 and 2017, amid increasing office capital value.

\section{$<<<$ Insert Figure 3 $>>>$}

Overall, major global events (or crisis), particularly the increase in uncertainty in global markets due to socio-economic and political trends, have been the source of much discussion and concern in recent years, in terms of the nature and severity of impacts on global real estate capital flows. The assessment of the impact of the 2007/2008 GFC and the ensuing recession on real estate capital flows into CBD office markets serves to highlight that the repercussions of the crisis, are to some extent, still apparent, however, the impacts are more severe in some cities than others. In terms of the London CBD office market, a drastic and significant fall in cross-border real estate investment activities can be seen at the start of the financial crisis. This was followed by recovery in 2008. A similar pattern is identified for the New York CBD office market, with a significant drop in real estate capital flows extending beyond 2008. However, for Tokyo, this trend was not replicated. Indeed, capital flows increased in 2008, before decreasing in 2009. These data also show that, despite the extent and severity of the crisis, the New York CBD office market was substantially impacted upon compared to the London and Tokyo markets.

\section{Internal transactions relative to cross-border trends}

The combined investment capital flow data for the three CBD office markets comprised 5,727 office properties transacted at over \$563B between 2007 - 2017. In order to facilitate the evaluation of the internal transactions relative to the cross-border trends, these investment transactions are classified as domestic investment; where both the selling and purchasing parties are based in the same country, and cross-border investment flows; where either (or both) parties are foreign based. Although cross-border investment flows play a highly significant role in each of the three global cities, there are major variations in the importance of the crossborder flows in each of the respective cities (Figure 4).

\section{$<<<$ Insert Figure 4>>>}


One of the most significant differences to arise between these global cities is the much greater penetration of cross-border investments in London consistently accounting for circa $82 \%$ of the total office market investments annually between 2007 and 2017, compared to the New York (38\%) and Tokyo (30\%) office markets. In terms of the actual cross-border investment volume, the London office market consistently attracts significantly higher cross-border investments than the other two cities, with the exception of 2016. In 2016, although the New York office market attracted more cross-border investments, surpassing that of London office market by $\$ 303 \mathrm{~m}$, cross-border investments accounted for a significantly lower proportion of the total investment levels in New York compared to the London office market. Whilst transactions in the New York and Tokyo office markets are largely dominated by domestic investments, the London office market appears much more dominated by cross-border investment activity and a wider geographical spread of the sources of capital inflows.

Indeed, analysis of the sources of cross-border investment activity indicates that inflows from over 63 countries entered into the London office market over the study period compared with inflows from 32 and 16 countries within New York and Tokyo respectively. This further highlights the London office market as the most international of the global cities. The analysis also shows that investors based in the US are the largest cross-border investor, an observation consistent with the findings of Zhu and Lizieri (2019), accounting for $24 \%$ of the total crossborder investments within the three cities and more specifically US investors are the largest foreign investor in London and Tokyo, accounting for $18 \%$ and $24 \%$ of cross-border investments respectively (Table 1).

Cross-border investments in each of the three cities are dominated by similar types of investors (Table 2). This similarity, suggests that some level of capital linkages may exist between the office markets respectively. However, further evaluation is warranted to examine the interaction and indeed level of integration between these CBD office markets and specifically their respective capital flows.

$<<<$ Insert Table 1 and $2>>>$

\section{Co-integration analysis and findings}

To analyse the level of interaction of international real estate capital flows between these CBD office markets, both long and short-run cointegration modelling and causality tests are employed to identify the associated relationships and the nature of the direction of causality 
between these real estate market capital flows. This provides a more granular and enhanced insight and understanding of how international capital flows in these cities interact over time, and importantly establishing the nature of the dependency.

\section{Augmented Dickey-Fuller Test}

Evaluation of the quarterly cross-border real estate capital flow data between the three cities over the period 2007-2017 indicates that both the London and New York capital flow variables are integrated at an order $I(1)$, whilst the Tokyo flow data shows an integration of $I(0)$ (Table 3). The optimal lag for the ADF test is selected automatically by the Akaike information criterion (AIC) with a maximum of 2 lags.

\section{$<<<$ Insert Table 3 $>>>$}

In light of the differences in terms of order of integration and stationarity, and in accord with extant research studies (Hamilton, 1994; Shrestha and Bhatta, 2018), the Auto-regressive Distributed Lag Approach (ARDL) specified by Pesaran and Shin (1999) and further enhanced by Pesaran et al. (2001) is the most applicable cointegration testing procedure. Furthermore, this ARDL methodology, as contended by Pesaran et al. (2001), is more efficient and robust in terms of (un)bias estimation as a consequence of small sample size when compared with other widely established procedures (Johansen, 1991; Harris and Sollis, 2003; Shrestha and Bhatta, 2018). Hence, the ARDL bounds cointegration technique is employed to empirically evaluate the long-run interaction amongst the London, New York, and Tokyo capital flows. The ARDL model(s) are expressed as follows:

London Cross-Border Capital Flow Model:

$$
\begin{aligned}
D\left(\operatorname{LLONCB}_{t}\right) & \\
& =\alpha_{01}+\beta_{11} L O N C B_{t-1}+\beta_{21} L N Y C B_{t-1}+\beta_{31} L T O K C B_{t-1}+ \\
& \sum_{i=1}^{p} \partial 1_{i} D\left(L L O N C \beta_{t-1}\right)+\sum_{i=1}^{q} \partial 2_{i} D\left(L N Y C \beta_{t-1}\right)+\sum_{i=1}^{q} \partial 3_{i} D( \\
& \left.\operatorname{LTOKC} \beta_{t-1}\right)+\varepsilon_{1 t}
\end{aligned}
$$

New York Cross Border Capital Flow Model: 


$$
\begin{aligned}
D\left(L N Y C B_{t}\right) & \\
& =\alpha_{02}+\beta_{12} L N Y C B_{t-1}+\beta_{22} L L O N C B_{t-1}+\beta_{32} L_{T O K C B} B_{t-1}+ \\
& \sum_{i=1}^{p} \partial 1_{i} D\left(L N Y C \beta_{t-1}\right)+\sum_{i=1}^{q} \partial 2_{i} D\left(L L O N C \beta_{t-1}\right)+\sum_{i=1}^{q} \partial 3_{i} D( \\
& \left.\operatorname{LTOKC} \beta_{t-1}\right)+\varepsilon_{2 t}
\end{aligned}
$$

Tokyo Cross Border Capital Flow Model:

$$
\begin{aligned}
D\left(\text { LTOKCB }_{t}\right) & \\
& =\alpha_{03}+\beta_{13} L T O K C B_{t-1}+\beta_{23} L L O N C B_{t-1}+\beta_{33} L N Y C B_{t-1}+ \\
& \sum_{i=1}^{p} \partial 1_{i} D\left(L T O K C \beta_{t-1}\right)+\sum_{i=1}^{q} \partial 2_{i} D\left(L L O N C \beta_{t-1}\right)+\sum_{i=1}^{q} \partial 3_{i} D( \\
& \left.L N Y C \beta_{t-1}\right)+\varepsilon_{2 t}
\end{aligned}
$$

Where all inflow variables are as previously defined in Table 3, D is the first difference operator, $\beta 1_{i}-\beta 3_{i}$ indicate the long-run relationship between the variables, with the sigma $\partial 1_{i}$ $-\partial 3_{i}$ representing the short-run dynamics and $\varepsilon_{t}$ the error terms.

The ARDL bounds test for cointegration is based on a two-stage procedure. The first accounts for the estimation of the three equations (6-8) by ARDL, with the second stage testing for the existence of long-run relationships amongst the capital flow variables employing the Wald test ( $F$-statistic) for the joint significance of the coefficients of the lagged levels of variables ${ }^{9}$. Indeed, as outlined by Pesaran et al. (2001) two critical values premised on upper and lower bounds are necessary for satisfying the cointegration test, as evidence in Table $4^{10}$.

\section{$<<<$ Insert Table 4 $>>>$}

For the London capital flow model (Table 4) the Wald statistic (2.021) signifies that the null hypothesis cannot be rejected indicating no long-run relationship or cointegration. In contrast, the New York capital flow model reveals a Wald statistic of $4.939(p<.05)$ thus rejection of the null and illustrating that cointegrating equations are present. This is also observable for the Tokyo capital flow model (Wald statistic $=9.558, p<.05$ ). In addition, decomposition of the

\footnotetext{
${ }^{9} \mathrm{H}_{0}: b_{1 \mathrm{i}}=b_{2 \mathrm{i}}=b_{3 \mathrm{i}}=0$ against the alternative $\mathrm{H}_{1}: b_{1 \mathrm{i}} \neq b_{2 \mathrm{i}} \neq b_{3 \mathrm{i}} \neq 0$.

10 The $\mathrm{H}_{0}$ is rejected when the estimated $F$-statistic is greater than the upper bound critical value, with the $F$ statistic below the lower bound critical value denoting that $\mathrm{H}_{0}$ cannot be rejected.
} 
bounds testing approach provides evidence of the long-run relationship between the variables in the model as follows:

Long-run London capital flow equation:

Cointeq $=$ LLONCB $-(-9.0724$ LNYCB $-93.4412 \mathrm{LTOKCB}+2112.9646)$

Long-run New York capital flow equation:

Cointeq $=$ LNYCB $-(2.5770 L L O N C B-1.1270$ LTOKCB -13.0221$)$

Long-run Tokyo capital flow equation:

Cointeq $=$ LTOKCB $-(0.0674$ LLONCB $+0.2222 \mathrm{LNYCB}+14.3185)$

The results of the long-run relationships between the markets illustrates that the capital flow variables for New York and Tokyo are not statistically significant at 5\% level in the London model (Table 5), inferring no long-run causal relationships between the investment activities in London CBD office market and the other office markets. With respect to the New York model, the results show that only the London capital flow coefficient is statistically significant at the 5\% level, suggesting a positive relationship between the New York and London office markets (in the long-run). Indeed, this implies that a $1 \%$ increase in cross-border investment activities within the London CBD office market will lead to an increase of circa $2.6 \%$ in crossborder capital flows towards the New York office market.

Moreover, examination of the long-run dynamics within the Tokyo model suggests a weaker relationship with New York capital flows only significant at the $10 \%$ level. This infers that a $1 \%$ increase in capital flows entering the New York office market will lead to around $0.22 \%$ increase in cross-border capital flows towards Tokyo. The findings do however illustrate no statistically significant causal relationships between London and Tokyo or indeed between Tokyo and New York, perhaps reflective of differences in market heterogeneity and size suggesting that other endogenous and exogenous dynamics are in operation which are affecting the inter-relationships of real estate capital flows.

$<<$ Insert Table 5 $>>>$ 


\section{ARDL Panel model}

We further investigate the relationships between the capital flows within a panel ARDL framework. The rationale for further undertaking the panel ARDL is to test and account for the simultaneous effects of the fund flows among the office markets. Since the capital flows are simultaneously affecting one another, a panel ARDL is envisaged to provide further understanding and reliable estimation of the effects. Indeed, the panel approach is generally applied when the foremost interest pertains to the "group" and not individual units in the group (Pesaran et al., 1997) which results in limited information being lost. In addition, further undertaking a panel approach increases the total number of observations whilst reducing the 'noise' which emerges in each respective separate time series estimation, thereby mitigating any potential effects of heteroscedasticity. Finally, panel estimation techniques take into account heterogeneity amongst units in the panel and is suited when examining the dynamic changes due to repeated cross-sectional observations by combining cross-section and time series observations. The panel ARDL is specified as follows:

$$
\Delta y_{i t}=\theta_{i}\left[y_{i, t=1}-\lambda_{i}^{\prime} X_{i, t}\right]+\sum_{j=1}^{p-1} \xi_{i j} \Delta y_{i, t=j}+\sum_{j=0}^{q-1} \beta_{i j}^{\prime} \Delta X_{i, t=j}+\varphi_{i}+\varepsilon_{i t}
$$

where $\boldsymbol{\theta}_{\boldsymbol{i}}=-\left(\mathbf{1}-\boldsymbol{\delta}_{\boldsymbol{i}}\right)$, is the group-specific speed of adjustment coefficient (expected that $\boldsymbol{\theta}_{\boldsymbol{i}}$ $<0) ; \boldsymbol{\lambda}_{\boldsymbol{i}}^{\prime}=$ vector of long-run relationships; ECT $=\left[\boldsymbol{y}_{\boldsymbol{i}, \boldsymbol{t}=\mathbf{1}}-\boldsymbol{\lambda}_{\boldsymbol{i}}^{\prime} \boldsymbol{X}_{\boldsymbol{i}, \boldsymbol{t}}\right]$, the error-correction term and $\xi_{i j}, \boldsymbol{\beta}_{i j}^{\prime}$ are the short-run dynamic coefficients

To test the stationarity of the variables (Table 6), the Levin et al. (2002) (LLC) and Im et al. (2003) panel unit root tests were conducted. While Levin et al. (2002) adopt a homogeneous self-regressive unit root under the alternative hypothesis, Im et al. (2003) assume a heterogeneous unit root under the alternative hypothesis. The results of the unit root tests (Table 7) for the series with intercept without trend show that the variables are stationary in level, thereby integrated to order $I(0)$.

\section{$<<<$ Insert Table 6 and $7>>>$}

The result of the PMG/Panel ARDL model (Table 8) reveals a negative and significant error correction term of $-0.489(\mathrm{p}<.05)$ thus the null hypothesis is rejected indicating that long-run cointegrating equations are present. This presence of the long-run relationships between the markets illustrate that the capital flow variable for the first city are not statistically significant 
at 5\% level, inferring no long-run causal relationship with the investment activities in the dependent city. The second city coefficient is statistically significant at the $5 \%$ level, suggesting a positive relationship between the dependent city and the second city office markets (in the long-run). This implies that a $1 \%$ increase in cross-border investment activities within the second city will lead to an increase of around $0.23 \%$ in the cross-border capital flows towards the dependent city office market in the long-run.

\section{$<<<$ Insert Table 8 $>>>$}

The heterogeneous panel estimations for each of the office markets (Table 9) show a significant negative speed of adjustment ranging from -0.287 to $-0.796(p<.05)$. This indicates that the cross-border capital flows towards the London, New York and Tokyo office markets adjust to the long-run equilibrium. However, the cross-border capital flows entering the London market indicates the lowest speed of adjustment relative to investment activities in both the respective Tokyo and New York markets. This finding implies that, although the process in the London office market converges over the long-run, the return to equilibrium will occur over a longer period compared with a deviation from the long-run equilibrium in New York and Tokyo. Further, in the London office market panel, the examination of the short-run dynamics reveals a negative relationship with the New York and Tokyo capital flows at the $1 \%$ level. This infers that a $1 \%$ increase in capital flows entering into New York and Tokyo will lead to circa $0.07 \%$ and $0.12 \%$ decrease (respectively) in cross-border capital flows towards the London office market.

The New York office market exhibits both positive and negative short-run relationship with Tokyo and London capital flows at $10 \%$ and 5\% level respectively. This suggests that a $1 \%$ increase in cross-border investment activity within the Tokyo office market will lead to a $0.14 \%$ increase in cross-border capital flows towards the New York office market in the short-run, while a similar increase in London capital flows will lead to a decrease of around $0.58 \%$ in cross-border investment activities in the New York office market. The Tokyo office market also reveals a negative short-run relationship with the London and New York capital flows at $1 \%$ level. This indicates that a $1 \%$ increase in capital flows entering the London and New York office markets will lead to around a $0.38 \%$ and $0.25 \%$ decrease (respectively) in cross-border investment activities in the Tokyo office market. 
In addition, in order to distinguish the directionality of the causal nature of the relationships evident between the selected office markets, the Pairwise Granger-Causality test is undertaken. The results, as observed in Table 10, are analogous with the more long-run Cointegration findings displaying that only a unidirectional causal relationship between London and New York exists as well as between New York and Tokyo at 1\% and 5\% level of significance respectively ${ }^{11}$. Importantly, the results show that London appears more independent and not affected by New York and Tokyo office markets.

\section{$<<<$ Insert Table 10 $>>>$}

\section{ARDL model diagnostics}

In order to account for model (systems equation) stability, a number of tests are performed, namely the Breusch-Godfrey Serial Correlation LM Test, Breusch-Pagan-Godfrey test for heteroscedasticity, CUSUM of square test and normality assumption using the Jarque-Bera test. As observed in Table 11, the tests show no presence of serial correlation $(p>.05)$ in any of the models, with the Jarque-Bera statistic also indicating no statistical significance and acceptance of the null hypothesis that the residuals are normally distributed. The BreuschPagan-Godfrey test for heteroscedasticity indicates heteroscedasticity $(p>.05)$ is present for all models except that of Tokyo (Table 11).

\section{$<<<$ Insert Table 11 $>>>$}

The CUSUM of square test results (Figure $5 a-c$ ) indicate that the plot of the CUSUM of square statistics fall within the critical bands of the $5 \%$ confidence interval of parameter stability. The result of the dynamic stability test also shows that no root lies outside the unit circle (Figure 6), thereby indicating the stability of the coefficients and validating the results of the three cross-border investment flow models.

\section{$<<<$ Insert Figure 5 and $6>>>$}

\section{Discussion}

The initial cointegration analysis observed within the ARDL model examined the interrelationships amongst the cross-border investments within the office markets of London,

\footnotetext{
11 The optimal lag for the model based on AIC is two lags
} 
New York and Tokyo. Pertinently, the findings signalled that the London market is seemingly not cointegrated with the New York and Tokyo market over the long-run, indicating that the level of integration between these cities (and markets) are not as interconnected or integrated as first envisaged. Furthermore, the direction of causality established through the long-run and short-run relationships suggested that New York and Tokyo markets have no causal relationship with the London market, though did illustrate that the London market leads the New York market which in turn leads the Tokyo market. Upon further inspection, the Panel ARDL estimation revealed that the cross-border capital flows are in fact cointegrated in the long-run, but showed that the speed of adjustment is more protracted for London - again symbolising that subtle differences are perhaps at play and that London acts more distinctively - arguably driven by cross-border activities and investor typologies. Further, in terms of shortrun adjustments, the analysis reveals capital flows entering into the New York and Tokyo markets impact negatively upon the London market with a similar picture evident for Tokyo with increases in capital flows in London and New York culminating in a decrease in crossborder investment. The New York market presents more mixed short-run effects, showing that increases in investment in Tokyo corresponds to an increase in cross-border capital flows in New York, albeit only at the 10\% level. Conversely, increases within London result in decreases of cross-border investment activities in the New York office market.

Overall, the findings appear to suggest that there are subtle differences in terms of the level of market integration between the office markets of New York, Tokyo and to a greater extent the London office market when considering the long and short-run effects and integration. Accordingly, there may be stylised facts in operation relating to underpinning market dynamics such as the level of financial integration between these markets and resulting investor behaviour within the real estate office markets in the post-GFC landscape. Indeed, the findings point towards patterns of capital flows in the post financial crisis landscape which share common elements related to the role of global imbalances which have been a key feature driving capital flows, in particular, the large supply of 'cheap' funds from China (Aizenman et al., 2013), as well as several other dimensions of heterogeneity.

Economic theory infers that international capital mobility permits savings, and investment, to be channelled towards markets (cities/countries) with fruitful investment opportunities ('safe havens' and a 'flight to quality') and for enhancing macroeconomic risk mitigation. This reallocation is, however, fraught with risks given the frictions that characterise both financial 
and real estate markets and the underpinning financial and capital flows. Movements within international capital flows, both direct and indirect can manifest in changes in portfolio with 'home bias' (reduction in the share of foreign assets held in an investor's portfolio) possibly remaining a characteristic of the post GFC New York and Tokyo markets and the weaker integration with the London market. The latter also appears to be perhaps reflective of the greater concentration of cross-border activity. As illustrated by Lizieri (2012), Tokyo and New York have historically been dominated by domestic transactions and capital, the results emanating from this research suggest that this remains the case as evidenced by the level of capital flows. Indeed, the findings indicate that London CBD office market was the prime destination of cross-border office investments between 2007 and 2017.

In terms of market integration, the financialisation of core markets was undoubtedly driven by risk shocks which play an obvious and crucial role in driving cross-border capital flows. The dramatic financial deepening and integration of wider capital and banking cross-border activity witnessed unprecedented increases in foreign ownership of domestic debt instruments during the build-up to the GFC. However, the subsequent global deleveraging and retrenchment within capital markets over the financial crisis period, including that by non-bank financial institutions, portfolio investment and FDI, appears to have shifted foreign ownership into prime real estate markets - principally London, as investors chase quality product and returns. Pertinently, the increase in risk aversion in the post GFC environment culminated in divestment within risky assets such as short-term debt and into perceived 'safer' assets with portfolio diversification in order to lower the risk exposure away from country-specific components. Nonetheless, and importantly, their behaviour for adjusting their portfolios to changes in returns as a consequence of adjustment costs has arguably meant that the speed at which capital flows adjust to changes in risk and in relative returns has increased sizeably at various points in the market cycle for each respective market driving the short-term differences.

As suggested by Milesi-Ferretti and Tille (2011), the GFC signalled a common shock for risk aversion and ultimately resulted in country-level characteristics becoming exogenous to the crisis given the heightened levels of capital integration and contagion, with country characteristics filtering the common shock into idiosyncratic outcomes across key markets. Arguably, therefore, the impact of the crisis resulted in a dramatic reassessment by investors of macroeconomic imbalances and financial vulnerabilities and risk tolerance, both actual and perceived within these core markets and seemingly the drive towards London offices is perhaps 
symbolic of this process in the immediate aftermath of the GFC. These market practices and rationale for increasing international portfolio diversification may also reflect the decline in home bias in the Tokyo and New York markets. Also, regulatory and tax arbitrage considerations played a very significant role in the expansion of cross-border real estate flows over the past decade. Moreover, fiscal policy responses impacting upon investment markets, such as constraining short-term interest rates, is often reflected in capital flow movements into and between real estate assets and markets.

Finally, whilst each market shares relatively similar levels of transparency and liquidity, the internationalisation of London seemingly attracts heightened levels of foreign investment more so than the other markets. There are numerous explanations for this as identified in the literature such as taxation and cultural impediments which may be causing friction to global capital flows into these two cities, thereby enhancing the attraction of London real estate investment market.

\section{Conclusion}

Over the last few of decades international capital flows have grown significantly reflecting many different issues such as structural flows for long-term investment purposes (FDI and related flows), portfolio flows, flows in debt instruments including bank flows and real estate capital flows. The GFC however brought an abrupt end to the sustained rise in capital flows and also international financial integration over the previous decade (Milesi-Ferretti and Tille, 2011). Thus, understanding international capital flows post GFC is highly relevant for policymakers, investors and real estate practitioners. Capital flows are important determinants of economic development and can provide mitigation against idiosyncratic shocks, yet, there remains more limited understanding of the pattern of capital flows within core real estate markets. Accordingly, the analysis presented in this paper highlighting the level of integration between the three core financial centres of London, Tokyo and New York and the significance of direct cross-border capital flows between them provides further insights and enhances the knowledge base.

Although the three global office markets are identified as top destinations for cross-border real estate investment, the analysis does suggest that there are variations in the market dynamics, 
with London seemingly the most dependent on international flows ${ }^{12}$. The findings in this regard showed that cross-border investments accounted for a substantial proportion of the total real estate investment activity in the office market, with a wider geographical spread of investment activities and investor types. In the case of New York and Tokyo, a different pattern emerged whereby domestic investments accounted for a major share of the total investment. The highlighted variation in the market dynamics can be attributed to subtle factors in the form of market practices and investor behaviour impacting on real estate investment flows into and within these three cities.

These subtle factors include changes in financial regulation, debt sustainability, fiscal policy and cultural hues causing friction to global capital flows into these office markets and enhancing the appetite for cross-border real estate within markets. Likewise, other factors such as the openness and reliability of the London CBD office market with specific reference to robustness of local laws and institutional frameworks, transparency, resilience, availability of suitable assets and the significance of the market in Europe in term of size and financial service sector enhances market transparency, liquidity and the perception of London as a safe haven relative to the other office markets.

This research also accentuates the significance of the direct cross-border flows in the London CBD office market in the last decade particularly as a major destination during the economic downturn. Ironically, increasing cross-border flows during this period potentially facilitated an asset market bubble and compression of yields due to limited quality stock. Furthermore, the seemingly more domestic focus of real estate capital flows into the New York and Tokyo office markets suggests that these markets are driven by different fundamentals and factors compared to that of London. Further research focusing on the relative significance of global factors to internal market conditions and wider capital flows is required to decipher the uniqueness of these international office markets. Moreover, future research should examine the determinants of the heterogeneity on capital flows as the slight diversity across the markets may be linked to the size of gross and net external exposures, and particularly to the reliance on debt instruments and the importance of bank cross-border activity. This should be further investigated to examine whether the cross-border real estate flows within these markets are interlinked to FDI or banking capital flows and indeed retrenchment.

\footnotetext{
12 This conclusion is based on the evaluation of the relative significance of the international capital flows to the domestic flows in the London market compared with the other two markets.
} 


\section{References}

Aizenman, J., Jinjarak, Y., and Park, D. (2013), "Capital flows and economic growth in the era of financial integration and crisis, 1990-2010”, Open Economies Review, Vol. 24 No.3, pp. 371-396.

Alfaro, L., Chanda, A., Kalemli-Ozcan, S., and Sayek, S. (2004), "FDI and economic growth: the role of local financial markets", Journal of international economics, Vol 64 No.1, pp. 89-112.

Antras, P., Desai, M. A., and Foley, C. F. (2009), "Multinational firms, FDI flows, and imperfect capital markets", The Quarterly Journal of Economics, Vol 124 No. 3, pp. 1171-1219.

Baum, A. (2015) Real Estate Investment: A strategic approach, $3^{\text {rd }}$ ed, Routledge, New York. Bergstrand, J. H. and Egger, P. (2007), "A knowledge-and-physical-capital model of international trade flows, foreign direct investment, and multinational enterprises", Journal of International Economics, Vol. 73 No. 2, pp. 278-308.

Blonigen, B. A. (2005), "A review of the empirical literature on FDI determinants", Atlantic Economic Journal, Vol. 33 No. 4, pp. 383-403.

Burrell, A. (2015), "Emerging International Real Estate Markets". IPF Research Programme Short Paper Series.

Cai, X. (2018), "Effects of Short-Term International Capital Flows on China's Real Estate Prices", Modern Economy, Vol. 9 No.1, pp.15-30.

Clayton, J., Ling, D. C., and Naranjo, A. (2009), "Commercial real estate valuation: fundamentals versus investor sentiment", The Journal of Real Estate Finance and Economics, Vol.38 No.1, pp. 5-37.

Darku, A.B. (2019), "Exports, capital inflows, relative prices, and income growth in South Korea: An application of the balance of payments constraint growth model", International Journal of Finance and Economics, Vol. 24, pp. 288- 295.

Dhar, R. and Goetzmann, W. N. (2006), "Institutional perspectives on real estate investing. The role of risk and uncertainty", Journal of Portfolio Management, Vol.32 No. 4, pp. 106-116.

Globerman, S., and Shapiro, D. (2002), "Global foreign direct investment flows: The role of governance infrastructure", World Development, Vol. 30 No.11, pp. 1899-1919.

Hamilton, J.D. (1994), Time Series Analysis, Princeton University Press, Princeton, New Jersey.

Fisher, J., Ling, D. C., and Naranjo, A. (2007), “Commercial Real Estate Return Cycles: Do Capital Flows Matter?”, working paper, University of Florida/RERI.

Haran, M., McCord, M., Davis, P., McCord, J., Lauder, C. and Newell, G. (2016), "European emerging real estate markets: Re-examining investment attributes and framing opportunities", Journal of Property Investment \& Finance, Vol. 34 No.1, pp. 27-50.

Harris, R. and Sollis, R. (2003), Applied Time Series Modelling and Forecasting, John Wiley and Sons, Chichester.

Hoyler, M., Lizieri, C., Pain, K., Taylor, P. J., Vinciguerra, S., Derudder, B. and Pelckmans, D. (2014), "European cities in advanced producer services and real estate capital flows: a dynamic perspective", in Pain, K. (Ed.), Changing Urban and Regional Relations in a Globalizing World. Europe as a Global Macro-Region, Edward Elgar, Cheltenham, pp. 115- 137.

Im, K., Pesaran, M. and Shin, Y. (2003), "Testing for unit roots in heterogeneous panels", Journal of Econometrics, Vol. 115, pp. 53-74.

Johansen, S. (1991), "Estimation and hypothesis testing of cointegration vectors in Gaussian vector autoregressive models", Econometrica, Vol. 59 No. 6, pp. 1551-1580.

Jones Lang LaSalle (2016), Global Real Estate Transparency Index 2016. 
Lee, H.K. (2013), "A cointegration analysis of inflation and real estate returns", Journal of Real Estate Portfolio Management, Vol.19 No. 3, pp. 207-224.

Levin, A., Lin, C. and Chu, C. (2002), "Unit root tests in panel data: asymptotic and finitesample properties", Journal of Econometrics, Vol. 108, pp. 1-24.

Ling, D. C., Marcato, G. and McAllister, P. (2009), "Dynamics of asset prices and transaction activity in illiquid markets: The case of private commercial real estate", The Journal of Real Estate Finance and Economics, Vol. 39 No. 3, pp. 359-383.

Ling, D., \& Naranjo, A. (2003). The dynamics of REIT capital flows and returns. Real Estate Economics, 31(3), 405-434.

Lipsey, R. E., Feenstra, R. C., Hahn, C. H. and Hatsopoulos, G. N. (1999), "The role of foreign direct investment in international capital flows", in National Bureau of Economic Research, International capital flows, University of Chicago Press, pp. 307-362.

Lizieri, C. (2009), Towers of Capital: Office Markets \& International Financial Services, Wiley-Blackwell, Chichester.

Lizieri, C. (2012), "Global Cities, Office Markets and Capital Flows", in Derudder, D., Hoyler, M., Taylor, P.J. and Witlox, F. (Ed.), International Handbook of Globalization and World Cities, Edward Elgar Publishing.

Lizieri, C. and Pain, K. (2014), "International office investment in global cities: the production of financial space and systemic risk", Regional Studies, Vol. 48 No. 3, pp. 439-455.

McAllister, P. and Nanda, A. (2016), "Does real estate defy gravity? An analysis of foreign real estate investment flows", Review of International Economics, Vol. 24 No. 5, pp. 924-948.

Milesi-Ferretti, G. M. and Tille, C. (2011), "The great retrenchment: international capital flows during the global financial crisis", Economic Policy, Vol. 26 No. 66, pp. 289-346.

Moshirian, F. and Pham, T. (2000), "Determinants of US investment in real estate abroad", Journal of Multinational Financial Management, Vol. 10 No. 1, pp. 63-72.

Newell, G., Adair, A. and McGreal, S. (2010), "Robustness of capital flows into the European commercial property markets during the global financial crisis. Journal of European Real Estate Research", Vol.3 No. 3, pp. 182-202.

Newell, G. and McGreal, S. (2017), "The significance of development sites in global real estate transactions", Habitat International, Vol. 66, pp. 117-124.

Pesaran, M. H., Shin, Y., and Smith, R. P. (1997), "Pooled Estimation of Long-Run Relationships in Dynamic Heterogenous Panels," DAE Working Papers Amalgamated Series 9721, University of Cambridge.

Pesaran, M. H. and Shin, Y. (1999) "An autoregressive distributed lag modelling approach to cointegration analysis", in Strom, S. (Ed.), Econometrics and Economic Theory in the 20th Century, The Ranger Frisch Centennial Symposium, Cambridge University Press.

Pesaran, M. H., Shin, Y. and Smith, R. J. (2001), "Bounds testing approaches to the analysis of level relationships", Journal of Applied Econometrics, Vol. 16, pp. 289-326.

PGIM Real Estate (2016), Global Outlook Cautious Optimism. Investment Research.

Razin, A. (2002), "FDI contribution to capital flows and investment in capacity", National Bureau of Economic Research, Working paper No. w9204.

Scott-Green, S. and Clegg, J. (1999), "The determinants of new FDI capital flows into the EC: a statistical comparison of the USA and Japan", Journal of Common Market Studies, Vol. 37 No. 4, pp. 597-616.

Shrestha, M. B. and Bhatta, G. R. (2018), "Selecting appropriate methodological framework for time series data analysis", The Journal of Finance and Data Science, Vol. 4 No. 2 , pp. 71-89.

Srivatsa, R. and Lee, S. L. (2012), "European real estate market convergence", Journal of Property Investment \& Finance, Vol. 30 No. 5, pp. 458-472. 
Stevenson, S., Akimov, A., Hutson, E. and Krystalogianni, A. (2014), "concordance in global office market cycles", Regional Studies, Vol. 48 No. 3,pp. 456-470.

Zhang, Y. (2018), "Impact of Short-Term International Capital Flows on Interactivity of Stock Market and Real Estate Market in Chinese First-Tier Cities: A Viewpoint of "CoSelling Effect", Journal of Financial Risk Management, Vol. 7. No. 1, pp. 1-11. 
Tables and Figures

Tables

Table 1: Top 10 investors by country of origin between 2007-2017.

\begin{tabular}{|c|c|c|c|c|c|}
\hline London & & New York & & Tokyo & \\
\hline United States & $18 \%$ & United States & $39 \%$ & Japan & $51 \%$ \\
\hline United Kingdom & $15 \%$ & China & $11 \%$ & United States & $24 \%$ \\
\hline Germany & $8 \%$ & Canada & $10 \%$ & Hong Kong & $5 \%$ \\
\hline Hong Kong & $8 \%$ & Germany & $6 \%$ & Germany & $3 \%$ \\
\hline Singapore & $4 \%$ & Norway & $5 \%$ & China & $2 \%$ \\
\hline Ireland & $3 \%$ & Israel & $5 \%$ & United Kingdom & $2 \%$ \\
\hline Canada & $3 \%$ & Qatar & $4 \%$ & South Korea & $2 \%$ \\
\hline China & $3 \%$ & United Kingdom & $3 \%$ & Australia & $1 \%$ \\
\hline Qatar & $3 \%$ & Japan & $2 \%$ & Singapore & $1 \%$ \\
\hline Spain & $3 \%$ & Switzerland & $2 \%$ & Norway & $1 \%$ \\
\hline
\end{tabular}

Table 2: Top 10 investors by investor type between 2007 and 2017.

\begin{tabular}{llllll}
\hline \multicolumn{1}{c}{ London } & \multicolumn{2}{c}{ New York } & & \multicolumn{2}{c}{ Tokyo } \\
\hline Developer/Owner/Operator & $17 \%$ & Developer/Owner/Operator & $22 \%$ & REOC & $21 \%$ \\
Investment Manager & $15 \%$ & Sovereign Wealth Fund & $15 \%$ & Developer/Owner/Op & $17 \%$ \\
Equity Fund & $14 \%$ & Investment Manager & $13 \%$ & Investment Manager & $13 \%$ \\
Sovereign Wealth Fund & $10 \%$ & Equity Fund & $11 \%$ & REIT & $10 \%$ \\
REOC & $10 \%$ & REOC & $7 \%$ & Bank & $9 \%$ \\
Bank & $8 \%$ & Insurance & $6 \%$ & Equity Fund & $9 \%$ \\
High Net Worth & $5 \%$ & High Net Worth & $6 \%$ & Insurance & $7 \%$ \\
Insurance & $4 \%$ & REIT & $5 \%$ & Corporate & $5 \%$ \\
Pension Fund & $4 \%$ & Pension Fund & $5 \%$ & Finance & $2 \%$ \\
REIT & $3 \%$ & Corporate & $4 \%$ & Open-Ended Fund & $1 \%$ \\
\hline
\end{tabular}

Table 3: Augmented Dickey-Fuller unit root test (intercept without trend)

\begin{tabular}{llllll}
\hline Transformed Variables & Variable Code & t-statistic & Prob & $\begin{array}{l}5 \% \\
\text { critical value }\end{array}$ & $\begin{array}{l}\text { Order of } \\
\text { Integration }\end{array}$ \\
\hline (In)London & LLONCB & -1.8349 & 0.3588 & -2.9369 & $\mathrm{I}(1)$ \\
(In)New York & LNYCB & -2.1268 & 0.2356 & -2.9332 & $\mathrm{I}(1)$ \\
(In)Tokyo & LTOKCB & -4.9895 & 0.0002 & -2.9314 & $\mathrm{I}(0)$
\end{tabular}

NB. (In) depicts the natural logarithm of cross border capital flows

Table 4: The ARDL bounds cointegration test results 


\begin{tabular}{lcccc}
\hline DV & Wald F-stat. & LBI(0) & UB I(1) & Cointegration \\
\hline LLONCB & $2.021^{*}$ & 3.1 & 3.87 & $\times$ \\
LNYCB & $4.939^{*}$ & 3.1 & 3.87 & $\checkmark$ \\
LTOKCB & 9.558 & 3.1 & 3.87 & $\checkmark$
\end{tabular}

\begin{abstract}
The AIC is used for the best model selection. Lower Bound: denotes 5\% significance, Upper Bound: denotes 5\% significance. NB: All the lower bound and upper bound critical values are obtained from Eviews based on Table CI (iii) Case II: Restricted intercept and no trend as discussed by Pesaran et al. (2001). *denotes 5\% significance.
\end{abstract}

Table 5: Results of the long-run ARDL model for the international capital flows.

\begin{tabular}{lcccccc}
\hline & \multicolumn{2}{c}{ London } & \multicolumn{2}{c}{ New York } & \multicolumn{2}{c}{ Tokyo } \\
\hline Variable & Coefficient & T-stat & Coefficient & T-stat & Coefficient & T-stat \\
& & & & & & \\
\hline Intercept & 2112.9 & 0.015 & -13.0221 & -0.7487 & $14.3185^{*}$ & 2.6358 \\
LNYCB & -9.0724 & -0.0145 & - & - & $0.2222^{*}$ & 1.8261 \\
LTOKCB & -93.4412 & -0.0149 & -1.127 & -1.2895 & - & - \\
LLONCB & - & - & $2.577^{*}$ & 2.9837 & 0.0674 & 0.2327 \\
\hline
\end{tabular}

*denotes significant at 5\% level.

Table 6: Summary of Variables for ARDL Panel model.

\begin{tabular}{llllll}
\hline Transformed Variable & Variable code & Mean & SD & Min & Max \\
\hline $\begin{array}{l}\text { (Ln) Dependent city cross-border capital } \\
\text { inflows }\end{array}$ & LCITYIF & 21.08 & 1.15 & 16.86 & 23.12 \\
(Ln) First city cross-border capital inflows & LFICITYIF & 21.08 & 1.15 & 16.86 & 23.12 \\
(Ln) Second city cross-border capital inflows & LSICITYIF & 21.08 & 1.15 & 16.86 & 23.12
\end{tabular}

NB: Maximum lag length 2 based on the AIC.

Table 7: Panel unit root test results

\begin{tabular}{|c|c|c|}
\hline \multirow[t]{2}{*}{ Variable } & \multicolumn{2}{|c|}{ Levels } \\
\hline & LLC & IPS \\
\hline LCITYIF & $-2.910 \quad(0.0018)$ & $-2.339(0.00$ \\
\hline
\end{tabular}




\begin{tabular}{llll}
\hline LFICITYIF & -2.910 & $(0.0018)$ & $-2.339(0.0096)$ \\
LSICITYIF & -2.910 & $(0.0018)$ & $-2.339(0.0096)$
\end{tabular}

Note: $p$-values are reported in the parenthesis. The null hypothesis is that of a unit root. The lags are chosen automatically using the AIC with maximum two lags. Levin, Lin \& Chu test (LLC), and Im, Pesaran, and Shin W-stat test (IPS).

Table 8: PMG long-run and ECM estimation (Dependent variable: LCITYIF)

\begin{tabular}{llll}
\hline Variable & Coefficient & t-statistic & Prob \\
\hline Long-run equation & & & \\
LFICITYIF & -0.0461 & -0.224688 & $(0.8226)$ \\
LSICITYIF & $0.2276^{* *}$ & 2.000818 & $(0.0478)$ \\
\hline ECM equation & & & \\
\hline ECT(-1) & $-0.4888^{* * *}$ & 0.1559 & $(0.0022)$ \\
D(LCITYIF(-1)) & $-0.2537^{* *}$ & -2.0965 & $(0.0383)$ \\
D(LFICITYIF) & -0.1013 & -0.6716 & $(0.5032)$ \\
D(LSICITYIF) & $-0.3152^{* *}$ & -2.3268 & $(0.0218)$ \\
C & $8.2888^{* * *}$ & 3.2951 & $(0.0013)$
\end{tabular}

NB. ${ }^{* * *}, * *$ and $*$ indicate significance at the $1 \%, 5 \%$, and $10 \%$ scales respectively. Values in parentheses are $p$-values.

Table 9: PMG heterogeneous Panel estimation

\begin{tabular}{llll}
\hline Variable & Coefficient & t-statistic & Prob \\
\hline London short-run coefficients & & & \\
ECT $(-1)$ & $-0.2866^{* * *}$ & -10.6078 & $(0.0018)$ \\
D(LCITYIF(-1)) & $-0.3032^{* * *}$ & -12.7838 & $(0.0010)$ \\
D(LNYCB) & $-0.0706^{* * *}$ & -25.9041 & $(0.0001)$ \\
D(LTOKCB) & $-0.1197^{* * *}$ & -17.8899 & $(0.0004)$ \\
C & 5.2233 & 0.7452 & $(0.5102)$ \\
\hline New York short-run coefficients & & \\
\hline ECT(-1) & $-0.3844^{* * *}$ & -16.9031 & $(0.0005)$ \\
D(LCITYIF(-1)) & $-0.4341^{* * *}$ & -18.9853 & $(0.0003)$ \\
D(LTOKCB) & $0.1432^{*}$ & 2.4917 & $(0.0884)$ \\
D(LLONCB) & $-0.5754^{* *}$ & -4.4708 & $(0.0209)$ \\
C & 6.3669 & 0.8301 & $(0.4674)$ \\
\hline Tokyo short-run coefficients & & & \\
\hline ECT $(-1)$ & $-0.7956^{* * *}$ & -29.6783 & $(0.0001)$ \\
D(LCITYIF(-1)) & -0.0238 & -1.3301 & $(0.2756)$ \\
D(LLONCB) & $-0.3764^{* * *}$ & -9.7189 & $(0.0023)$ \\
D(LNYCB) & $-0.2505^{* * *}$ & -49.2360 & $(0.0000)$ \\
C & 13.2763 & 0.7067 & $(0.5307)$ \\
\hline NB. ${ }^{* * *},{ }^{* *}$ and ${ }^{*}$ indicate significance at the $1 \%, 5 \%$, and $10 \%$ scales respectively. & \\
Values in parentheses are $p$ - values. & & & \\
\end{tabular}


Table 10: Pairwise Granger causality tests

\begin{tabular}{lc}
\hline Direction of Causality & $F$-Statistic \\
\hline LNYCB > LLONCB & 1.54283 \\
LLONCB > LNYCB & $6.13024 * * *$ \\
LTOKCB > LLONCB & 0.0455 \\
LLONCB > LTOKCB & 1.29664 \\
LTOKCB > LNYCB & 2.11267 \\
LNYCB > LTOKCB & $4.59626^{* *}$ \\
\hline
\end{tabular}

Note: > denotes ' does not Granger Cause',

**denotes 5\%; *** denotes $1 \%$.

F-statistics derived from the Wald test: $\mathrm{B}_{1}=\mathrm{B}_{2}=\ldots \mathrm{B}_{\mathrm{I}}=0$

\section{Table 11: Model Diagnostic tests}

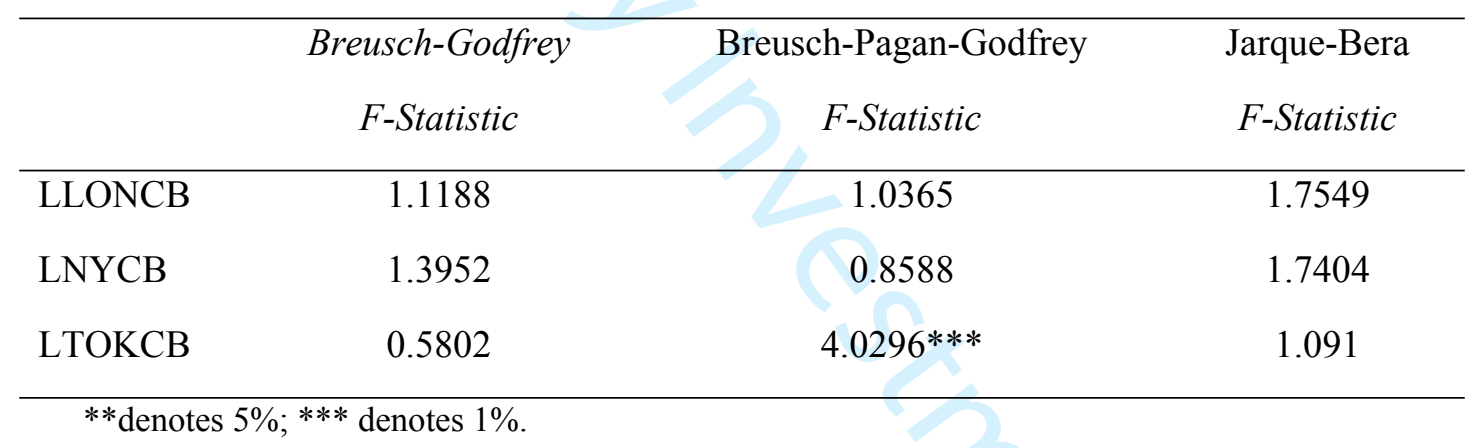




\section{Figures}

Figure 1: Total annual transaction volume versus number of deals completed

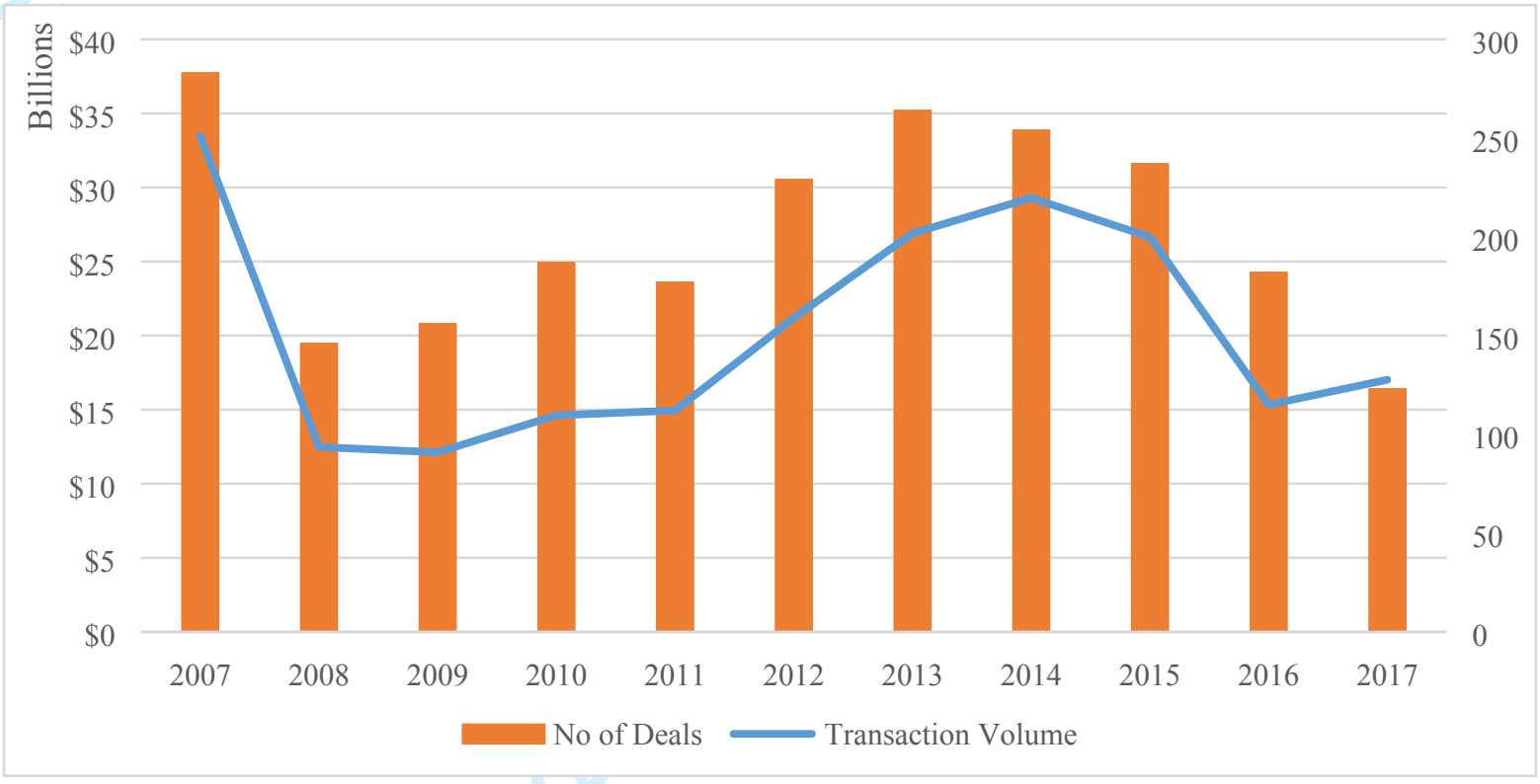

Source: $R C A$

Figure 2: Total annual transaction volume versus number of deals completed

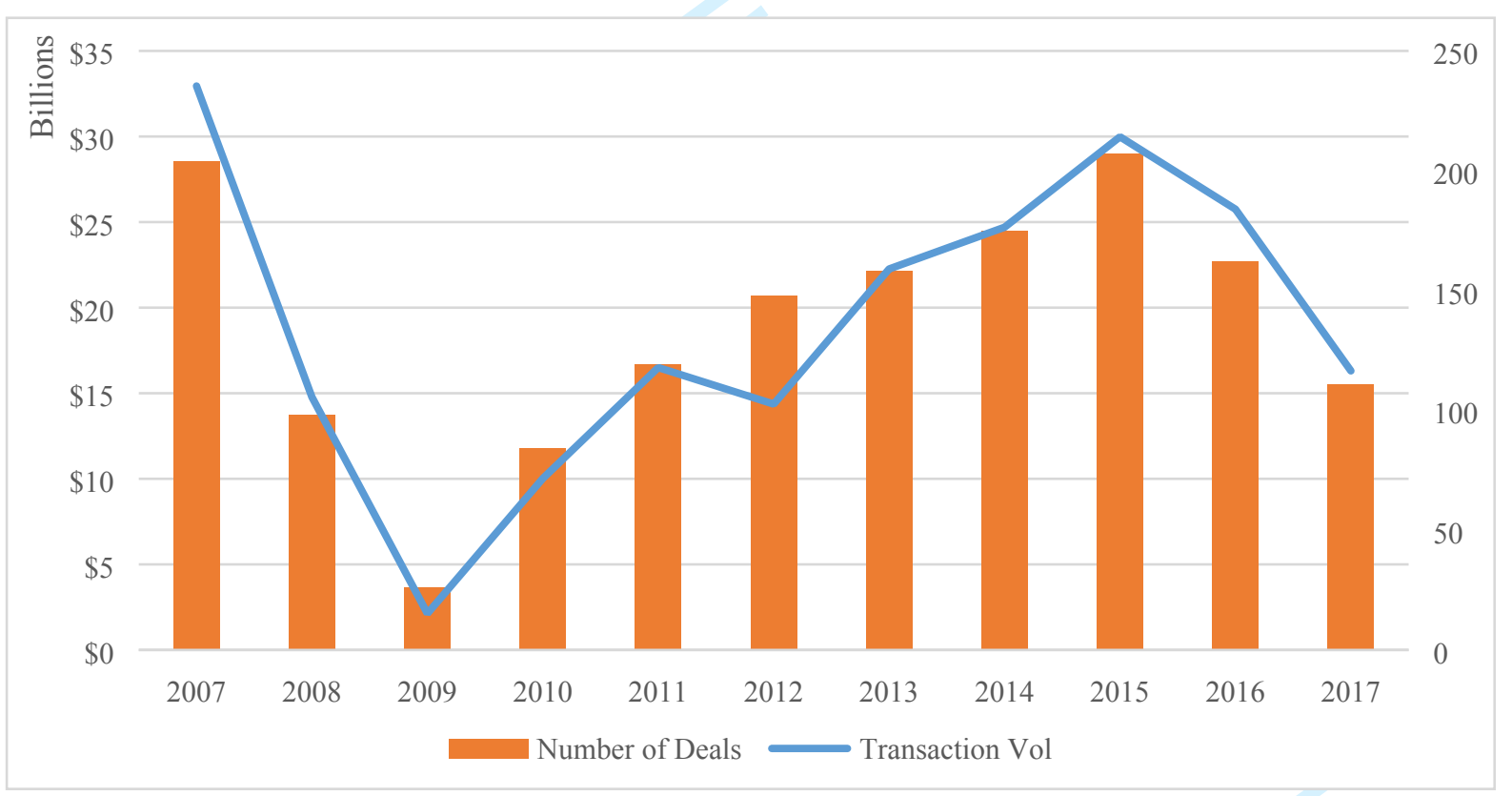

Source: $R C A$ 
Figure 3: Total annual transaction volume versus number of deals completed

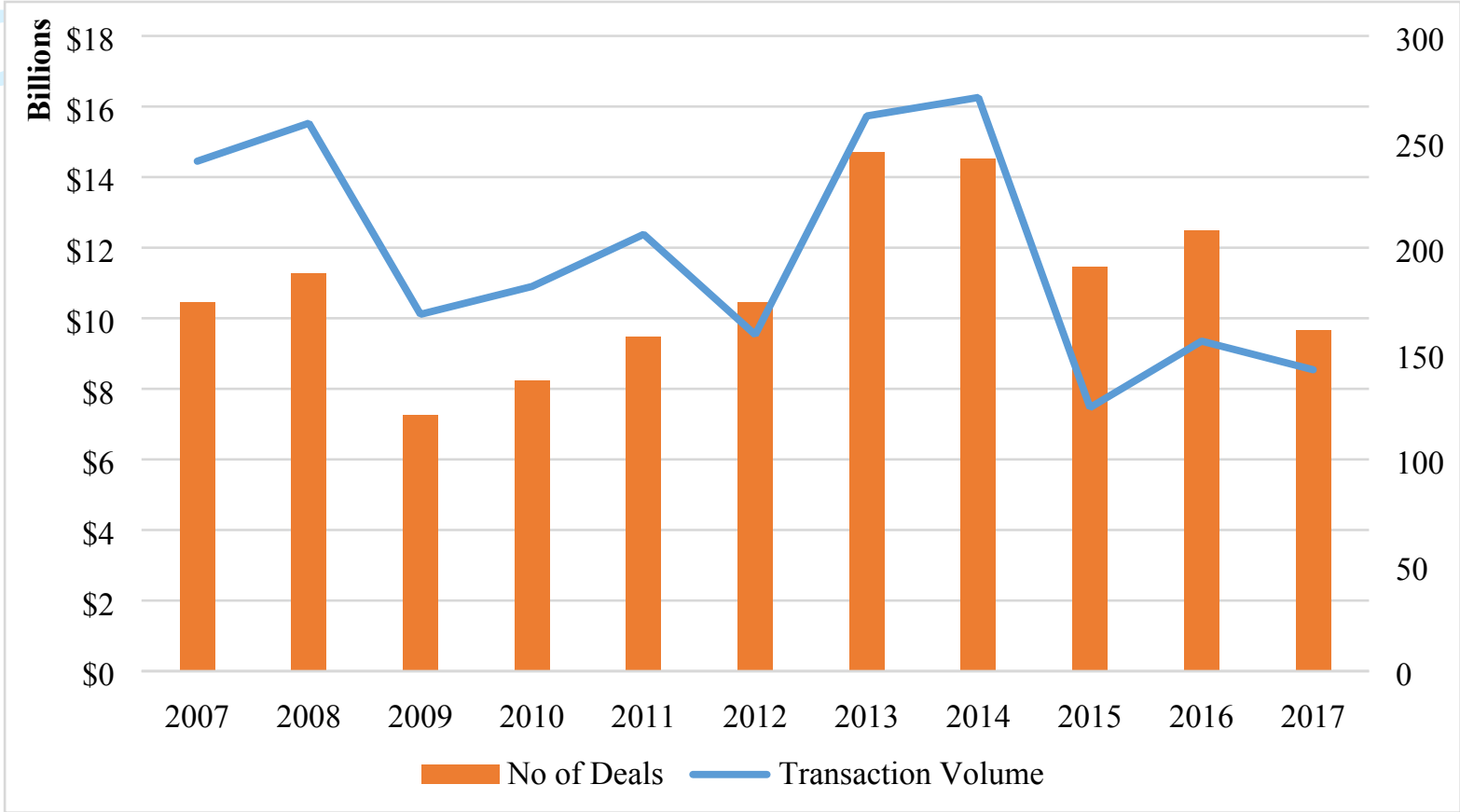

Source: $R C A$

Figure 4: Domestic versus Cross-Border Capital Flows

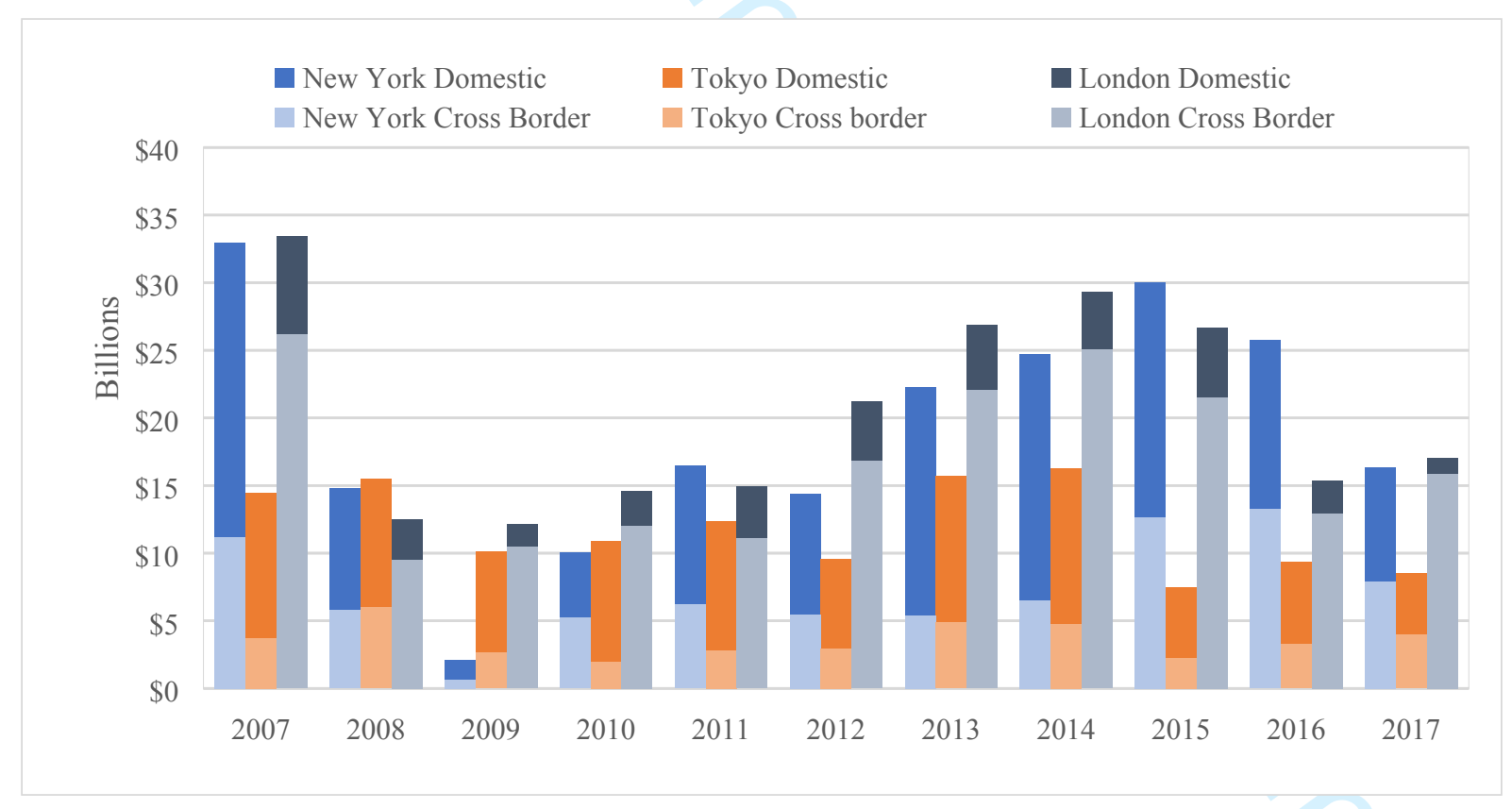

Figure 5: The CUSUM of square test results

(a)London equation

(b) New York equation 


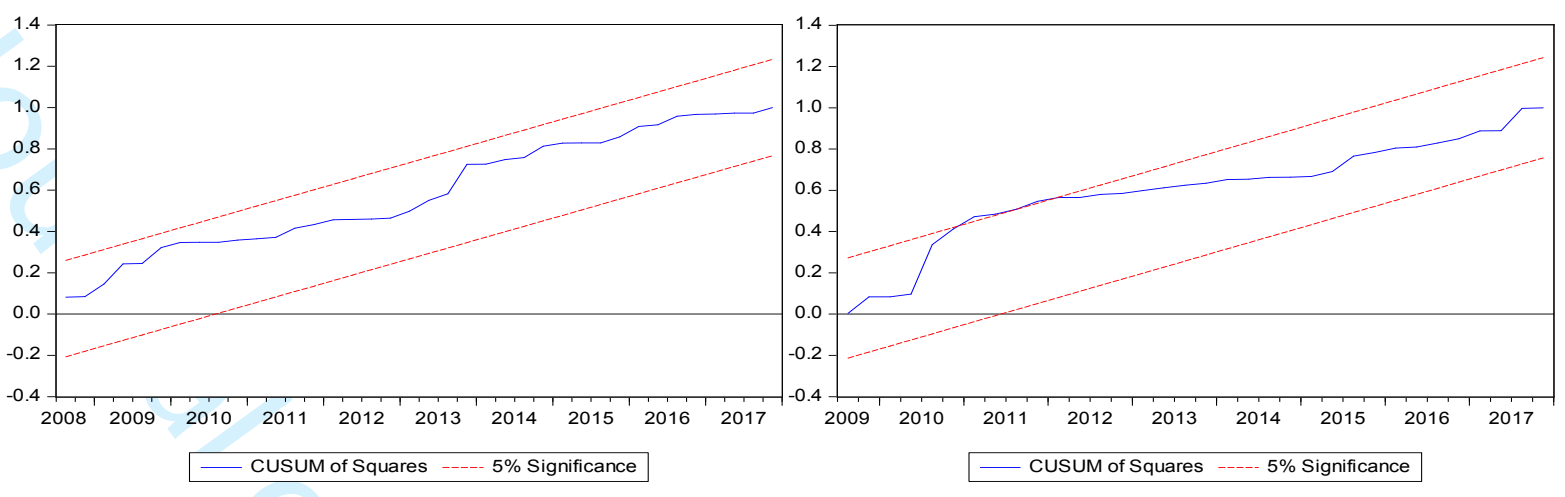

(c)Tokyo equation

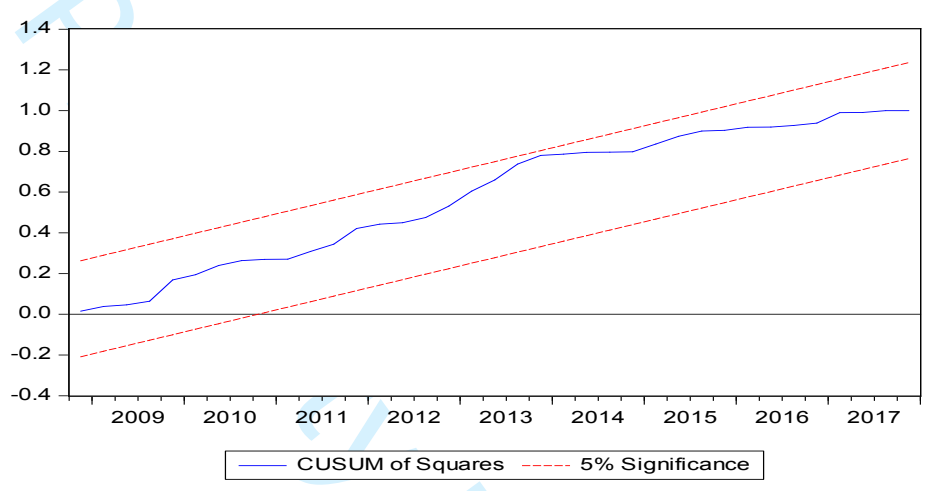

Figure 6: Dynamic stability test: Inverse roots of AR characteristic polynomial

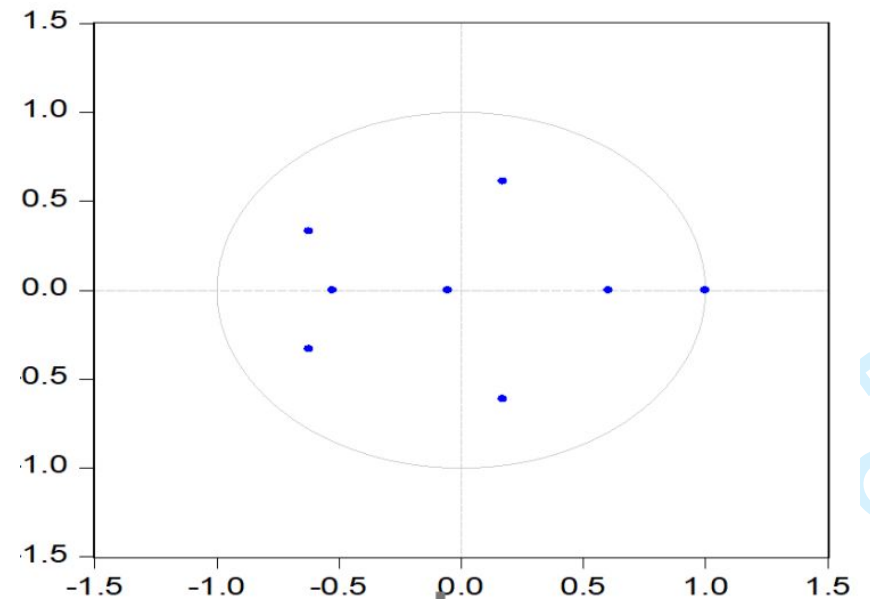

